\title{
A Systematic Review on the Efficacy of Iontophoresis as a Treatment for Lateral Epicondylitis
}

\author{
James McKivigan*, Brent Yamashita and Derek Smith \\ Touro University, USA \\ ${ }^{*}$ Corresponding author: James McKivigan, Touro University, Nevada, USA \\ Submission: 眥 October 06, 2017; Published: 覀 November 15, 2017
}

\begin{abstract}
Background and purpose: It is still inconclusive which method of iontophoresis delivers the most medication deepest through the skin, and therefore most effective in treating lateral epicondylitis. The purpose of this systematic review is to analyze the efficacy of treatments for lateral epicondylitis using iontophoresis.

Method: The review included articles from peer-reviewed journals with sufficient data related to the purpose and focus of the study. Inclusion criteria included randomized control trials, cohort studies, case studies, systematic reviews, meta-analyses, and pilot studies published since 2000.

Results: Fourteen relevant studies were identified. Twelve were experimental in vivo studies, two were review studies. All studies were published 2002 through 2015, providing a robust overview of treatments over the last 15 years.

Discussion and conclusion: Among studies in this systemic review, pooled data from RCTs pointed to minimal intermediate- to long-term clinical benefit for the nonsurgical treatment of lateral epicondylitis. Of drug treatments, the most frequently used in iontophoresis are dexamethasone and lidocaine. Studies of iontophoresis with dexamethasone show evidence that the combination of treatments may be effective in reducing pain; there is evidence supporting the iontophoretic administration of dexamethasone as an alternative to other medication and oral therapy. Based on this review, it is not conclusive that iontophoresis be recommended as a treatment approach for the management of epicondylitis, however iontophoresis should not be ruled out in treating epicondylitis as it is a dose-response modality. More research and review of research is needed on the use of iontophoresis in managing epicondylitis.
\end{abstract}

Keywords: Iontophoresis; Lateral epicondylitis; Drug-delivery; Transcutaneous; Tendinopathy

\section{Introduction}

Lateral epicondylitis, or tennis elbow, is a painful condition typically caused by overuse of the tendons, resulting in tendinopathy, inflammation, pain, and tenderness to the lateral elbow. The condition involves the extensor carpi radialis brevis, part of the wrist extensor musculature. These extensor muscles of the forearm help stabilize the wrist to create a useful and powerful grip of the hand. As many as $15 \%$ of workers making highly repetitive motions with their hands contract this condition and on average lose up to 12 weeks of work [1]. Several treatments for lateral epicondylitis exist. One treatment is iontophoresis, a technique that delivers a medicine through the skin using electrical current, also called transdermal delivery. This technique enhances the absorption of drugs across biological tissue such as skin. Traditionally, iontophoresis involves a machine utilizing direct current with lead wires. Using a dosage up to $5 \mathrm{~mA}$ a treatment would last between 16 minutes and 30 minutes. Currently, clinicians use iontophoresis as an adjunct intervention treatment for lateral epicondylitis, as well as other conditions.

Many advances in iontophoresis have occurred since then. Advances in newer technologies have also occurred. Recently, therapists have been using a self-contained patch that relies on no wires. The patch uses a very low current, less than $1 \mathrm{~mA}$, to deliver the medication over a span of up to 14 hours. However, there is not much research to date on its effectiveness compared to traditional iontophoresis. Other forms of treatment also exist, including Lidocaine and Dexamethasone. Lidocaine is within the category of drugs that includes local anesthetics. The drug is administered topically using a transdermal patch and a low-grade electrical current from an iontophoresis unit [2]. The main benefit of lidocaine is that it admits analgesic effects to a particular area of the body so that treatment can occur with less pain [3]. The other common drug treatment for epicondylitis is Dexamethasone, a synthetic derivative of glucocorticoid steroid that is 25 times more efficient in reducing inflammation, with little retention of sodium [2]. The glucocorticoids inhibit the release of inflammatory proteins; however the method by which the glucocorticoids attenuate heat, swelling, erythema, and tenderness is not completely understood. Overall, the results with dexamthasone have been found to be remarkable.

It is known that medications can be very effective when treating soft tissue injuries, but often injections are the primary method 
by medical doctors for such conditions. Iontophoresis is the most common non-invasive treatment using medications. A few studies have been conducted on iontophoresis; however most have been on the effects of different medications. Many studies have also looked at the effectiveness of a particular medication for lateral epicondylitis. When using iontophoresis, it is still inconclusive which method can deliver the most medication deepest through the skin, and which drug provides the most efficient treatment of lateral epicondylitis. By learning the best method and medicationsto treat lateral epicondylitis, physical therapists can provide individuals with this debilitating disorder greater improvement and outcomes of movement. The purpose of this systematic review is to provide physical therapy clinicians with pertinent information regarding progression of lateral epicondylitis treatment using iontophoresis and to analyze the evidence for the efficacy of the method in physical therapy.

\section{Methods}

The following databases were searched for relevant articles: PubMed, Cochrane Library, PEDro, SPORT Discus, Google Scholar, and the APTA library. Key words consistently used during the search were "lateral epicondylitis," "epicondylitis," "epicondylalgia," "iontophoresis," "trans-dermal," "effectiveness," "dexamethasone," "lidocaine," and "physical therapy." Abstracts of all the articles retrieved were reviewed to determine relevancy. Full peer-reviewed articles that fit the inclusion criteria were retrieved. In addition, a manual search was conducted of references within relevant articles and obtained for a full assessment.

\section{Eligibility criteria}

This systematic review included articles found in peerreviewed journals with sufficient data related to the purpose and focus of the study. The inclusion criteria included randomized control trials, cohort studies, and case studies, systematic reviews, meta-analyses, and pilot studies. Extensive findings were narrowed down to a core of relevant literature published since 2000. Articles published before 2000 were excluded during the search, however were kept for any relevant background information. Also excluded were articles published in languages other than English that did not have an English version published. Additional exclusion criteria included retrospective studies, case studies, lack of study design description or had no full text available.

\section{Critical appraisal}

Two types of critical appraisal strategies were used for this study: the Physiotherapy Evidence Database (PEDro) scale and the AMSTAR scale. The PEDro scale was used to assess the quality of each randomized controlled trials (RCT). The AMSTAR scale was used to assess the quality of both a meta-analysis and a systematic review.

\section{Data Extraction and Analysis}

All relevant articles that met the inclusion criteria were prepared for assessment using a data extraction form. All literature has data extracted using the Cochrane data extraction sheet for systematic reviews. The data sheet helped in the correlation and comparison of necessary information including but not limited to the type of intervention, blinding of subjects, outcomes, method of subject selection, and comparison of experimental and control groups. The information from these forms was assessed for quality and validation of all obtained articles. The PEDro scale was used to evaluate the quality of each RCT. For studies retrieved from the Pedro database, the Pedro scores provided were accepted. The Pedro rating tool comprised eleven items. Items where criteria were fulfilled were scored with a "+," a "-" if the criteria were not fulfilled, and "?" if the provided information was unclear, and considered *not fulfilled.

The items rated are as follows:

1) Eligibility criteria were specified,

2) Subjects were randomly allocated to groups (in a crossover study, subjects were randomly allocated to an order in which treatments were received),

3) Allocation was concealed,

4) The groups were similar at baseline regarding the most important prognostic indicators,

5) There was blinding of all subjects,

6) There was blinding of all therapists who administered the therapy,

7) There was blinding of all assessors who measured at least one key outcome,

8) Measures of at least one key outcome were obtained from more than $85 \%$ of the subjects initially allocated to groups,

9) All subjects for whom outcome measures were available received the treatment or control condition as allocated or, where this was not the case, data for at least one key outcome were analyzed by "intention to treat,"

10) The results of between-group statistical comparisons are reported for at least one key outcome, and

11) The study provides both point measures and measures of variability for at least one key outcome [4].

Additonally, the quality of all studies were assessed using the Oxford Centre for Evidence-based Medicine Levels of Evidence, which grades the quality of research and includes five levels of recommendations:

(A) Consistent level 1 studies (very good quality)

(B) Consistent level 2 studies or extrapolations from level 1 studies (good quality)

(C) Consistent level 3 studies or extrapolations from level 2 studies (moderate quality)

(D) Level 4 studies or extrapolations from level 2 or 3 studies (low quality) 
(E) Level 5 evidence or troublingly inconsistent or inconclusive studies of any level (very low quality)

\section{Results}

\section{Selection of studies}

The database search yielded to 48 possibly eligible studies. After reviewing titles and abstracts, the search was reduced to 16 studies. Two papers were excluded because one did not meet criteria and one was a duplicate that had not yet been removed. Among the resulting 14 relevant studies, 12 were experimental in vivo studies, while two were review studies. The latter is used within the discussion section only. All the papers were published in medical journals, two of them in the Journal of Orthopedic \& Sports Physical Therapy [5] and the rest of different prestigious journals. The publication years were all 2002 and later; one study was published in 2002, three in 2003, one each in 2006, 2008, 2011, and 2012 , and three in 2015, giving a robust overview of the treatment and review of the problem over the last 15 years.

\section{Methodological quality}

The quality of the study designs ranged from Pedro scores of 3 to 11 out of 11 . Studies with a Pedro score of 7 and above were rated "high," those with a Pedro score of 5 or 6were rated as "moderate," and those with a Pedro score of 4 or below were rated as low-quality studies. The mean Pedro score for the 11 studies reporting positive effects of iontophoresis treatment was $6.27 \pm 2.52$ SD, while one study with a negative treatment outcome had a Pedro score of 8 , indicating a moderate quality of research in this topic area. Patient randomization was done in seven of the studies, indicative of a good-quality research paper. Blinding was the most lacking in the Pedro score; due to the nature of the interventions, it is not possible for patients or care providers to be blinded. Patient blinding, care provider blinding, and outcome assessment blinding was done in only three studies [5-7]. Patient allocation was most often judged as unclear and has a low Pedro score review. These items were therefore considered unacceptable, especially blinding.

The Oxford Centre for Evidence-based Medicine Levels of Evidence was used to assess evidence. Two studies were found with a reported level $1 b[6,8]$. One study reported level 2a (good quality [9]). Five studies were reported level $2 b$ (good quality [5,7]). Two studies were reported level 3b (moderate quality; Draper et al. [3]), and two were reported level 4 (low quality $[5,10]$ ).

\section{Discussion}

The purpose of this systematic review is to provide physical therapy clinicians with pertinent information regarding progression of lateral epicondylitis treatment using iontophoresis and to analyze evidence for the efficacy of the method in physical therapy. After searching databases in combination with reference checking for randomized controlled clinical trials, a total of 12 studies were analyzed. All 12 studies report the effectiveness of iontophoresis in the management of epicondylitis and are displayed in the table below Table 1.

Table 1: Descriptive characteristics of the included studies assessing treatments of lateral epicondylalgia.

\begin{tabular}{|c|c|c|c|c|c|c|c|c|}
\hline $\begin{array}{l}\text { Author \& } \\
\text { Year }\end{array}$ & $\begin{array}{l}\text { Study } \\
\text { Design }\end{array}$ & Participants & Diagnosis & $\begin{array}{l}\text { Treatment } \\
\text { Frequency }\end{array}$ & Intervention & Comparison & $\begin{array}{l}\text { Outcome } \\
\text { Measures }\end{array}$ & Results \\
\hline $\begin{array}{l}\text { Stefanou } \\
\text { et al. [9] }\end{array}$ & Randomized & 82 patients & lateral & $\begin{array}{l} \\
\\
\text { Group 1=24 } \\
\text { hour battery; } \\
\text { Group 2=single } \\
\text { injection; } \\
\text { Group 3: single } \\
\text { injection }\end{array}$ & $\begin{array}{l}\text { Coup 1: 10mg of } \\
\text { Group } \\
\text { dexamethasone via } \\
\text { iontophoresis using self- } \\
\text { contained patch with a } 24- \\
\text { hour battery (n=31); Group } \\
\text { 2 10mg dexamethasone } \\
\text { injection (n=27); Group } \\
\text { 3: 10mg triamcinolone } \\
\text { injection (n=28). }\end{array}$ & $\begin{array}{c}\text { delivery of } \\
\text { dexamethasone } \\
\text { compared to } \\
\text { corticosteroid } \\
\text { injection } \\
\text { therapy } \\
\text { n patient } \\
\text { outcomes }\end{array}$ & $\begin{array}{l}\text { Change in } \\
\text { grip strength } \\
\text { (flexion vs. } \\
\text { extension), pain, } \\
\text { function scores } \\
\text { on a validated } \\
\text { questionnaire; } \\
\text { secondary } \\
\text { outcome was } \\
\text { return-to-work } \\
\text { status; evaluated } \\
\text { at baseline, } \\
\text { completion of } \\
\text { physical therapy, } \\
\text { and 6-month } \\
\text { follow-up. }\end{array}$ & 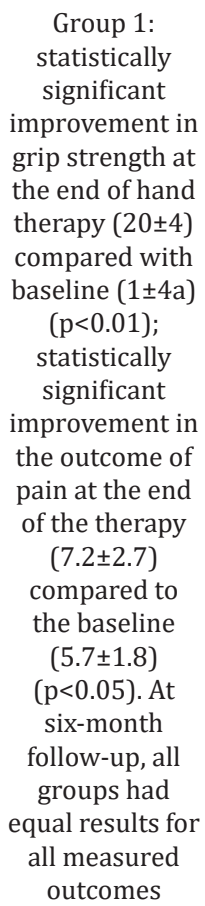 \\
\hline
\end{tabular}




\begin{tabular}{|c|c|c|c|c|c|c|c|c|}
\hline $\begin{array}{l}\text { Nirschl et } \\
\text { al. [6] }\end{array}$ & $\begin{array}{l}\text { double- } \\
\text { blinded } \\
\text { randomized } \\
\text { placebo- } \\
\text { controlled }\end{array}$ & 199 & $\begin{array}{l}\text { medial } \\
\text { and lateral } \\
\text { epicondyitis }\end{array}$ & $\begin{array}{l}6 \text { treatments, } \\
\text { over } 15 \text { days, } 1-3 \\
\text { days apart }\end{array}$ & $\begin{array}{l}40 \mathrm{~mA} \text {-minutes of either } \\
\text { active }(n=99) \text { or placebo } \\
\text { treatment }(n=100)\end{array}$ & $\begin{array}{c}\text { transdermal } \\
\text { administration } \\
\text { of } \\
\text { dexamethasone } \\
\text { sodium } \\
\text { phosphate }\end{array}$ & pain & $\begin{array}{c}\text { Reduced } \\
\text { symptoms } \\
\text { of medial } \\
\text { or lateral } \\
\text { epicondylitis } \\
\text { with significant } \\
\text { pain reduction } \\
\text { for the patients } \\
\text { (p<0.05); } \\
\text { significant } \\
23 \mathrm{~mm} \\
\text { improvement } \\
\text { on the } 100 \mathrm{~mm} \\
\text { patient visual } \\
\text { analog scale } \\
\text { ratings. }\end{array}$ \\
\hline $\begin{array}{l}\text { Wen et al. } \\
\text { [8] }\end{array}$ & RCT & 28 adults & $\begin{array}{l}\text { chronic lateral } \\
\text { epicondylitis }\end{array}$ & $\begin{array}{l}\text { Experimental } \\
\text { group: } 3 \text { sets of } \\
\text { 15repetitions } \\
\text { daily, met with } \\
\text { the therapist } \\
\text { twice a week } \\
\text { for the first } 2 \\
\text { weeks, then } \\
\text { once per week } \\
\text { for } 12 \text { weeks; } \\
\text { control group: } \\
\text { same schedule } \\
\text { as experimental } \\
\text { group }\end{array}$ & $\begin{array}{c}\text { Experimental group } \\
(\mathrm{n}=14) \text { of eccentric } \\
\text { strengthening group and } \\
\text { the control group }(\mathrm{n}=14) \\
\text { local modality treatments } \\
\text { and iontophoresis }(2 \mathrm{~mL} \text { of } \\
4 \% \text { dexamethasone with a } \\
40 \mathrm{~mA} / \mathrm{min}) .\end{array}$ & $\begin{array}{l}\text { wrist extensor } \\
\text { eccentric } \\
\text { strengthening } \\
\text { exercise } \\
\text { program against } \\
\text { a wrist extensor } \\
\text { stretching/ } \\
\text { modality } \\
\text { program }\end{array}$ & pain & $\begin{array}{l}\text { Overall } \\
\text { satisfaction and } \\
\text { grip strength } \\
\text { showed no } \\
\text { statistically } \\
\text { significant } \\
\text { differences } \\
\text { between the } \\
\text { groups. For the } \\
\text { control group, } \\
\text { a statistically } \\
\text { significant } \\
\text { decrease of } 28 \\
\text { points occurred } \\
\text { between } \\
\text { baseline and } \\
\text { the four-week } \\
\text { follow-up } \\
\text { with P <0.01. } \\
\text { Secondary } \\
\text { outcomes } \\
\text { indicated a } \\
\text { statistically } \\
\text { significant } \\
\text { improvement } \\
\text { in pain level } \\
\text { compared } \\
\text { with baseline } \\
\text { favoring the } \\
\text { eccentric } \\
\text { strengthening } \\
\text { group at the } \\
\text { eight-week time } \\
\text { point. }\end{array}$ \\
\hline $\begin{array}{l}\text { Runeson } \\
\text { et al. [7] }\end{array}$ & $\begin{array}{c}\text { RCT and } \\
\text { double- } \\
\text { blinded study }\end{array}$ & 64 & $\begin{array}{c}\text { lateral } \\
\text { epicondylalgia }\end{array}$ & $\begin{array}{l}\text { Four times over } \\
2 \text { weeks }\end{array}$ & corticosteroid or placebo & $\begin{array}{l}\text { short- and } \\
\text { long-term } \\
\text { pain-relieving } \\
\text { effect of } \\
\text { dexamethasone } \\
\text { iontophoresis } \\
\text { versus placebo } \\
\text { iontophoresis }\end{array}$ & $\begin{array}{c}\text { Subjective } \\
\text { and objective } \\
\text { outcomes } \\
\text { of pain and } \\
\text { grip strength; } \\
\text { evaluated day } \\
\text { after final } \\
\text { treatment and } \\
\text { after } 3 \text { and } 6 \\
\text { months }\end{array}$ & $\begin{array}{c}\text { Differing } \\
\text { results from } \\
\text { other papers, } \\
\text { showing no } \\
\text { significant } \\
\text { difference in } \\
\text { pain relief } \\
\text { between the } \\
\text { corticosteroid } \\
\text { group (n=33) } \\
\text { and the placebo } \\
\text { group }(\mathrm{n}=31) .\end{array}$ \\
\hline
\end{tabular}




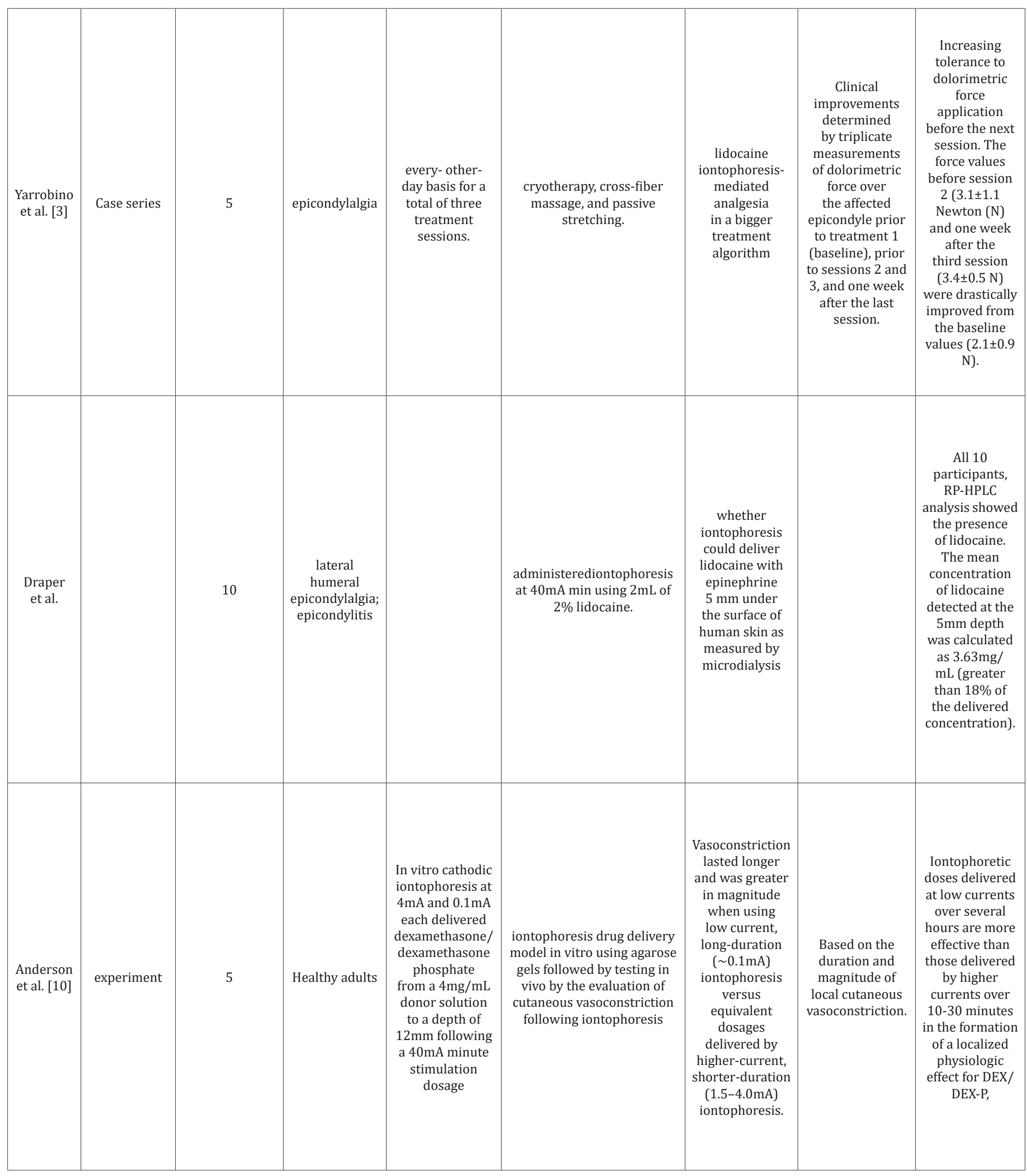




\begin{tabular}{|c|c|c|c|c|c|c|c|c|}
\hline $\begin{array}{l}\text { Anderson } \\
\text { et al. [10] }\end{array}$ & experiment & 5 & Healthy adults & & $\begin{array}{l}\text { vitro evaluations of } \\
\text { dexamethasone phosphate } \\
\text { iontophoresis and in vivo } \\
\text { estimations of drug amounts } \\
\text { (milligrams) provided via } \\
\text { iontophoresis }\end{array}$ & $\begin{array}{l}\text { optimal } \\
\text { parameters } \\
\text { required for } \\
\text { the clinical } \\
\text { iontophoresis of } \\
\text { dexamethasone } \\
\text { phosphate }\end{array}$ & & $\begin{array}{l}\text { Increased } \\
\text { dexamethasone } \\
\text { phosphate } \\
\text { delivery } \\
\text { with higher } \\
\text { iontophoretic } \\
\text { dosages and } \\
\text { with the pure } \\
\text { dexamethasone } \\
\text { phosphate } \\
\text { formulation. } \\
\text { After an } \\
\text { 80-mA-minute } \\
\text { drug delivery } \\
\text { had been } \\
\text { administered, } \\
\text { the in vivo } \\
\text { iontophoretic } \\
\text { delivery was } \\
\text { measured } \\
\text { at } 1.40 \\
\text { +/- } 0.23 \text { mg, } \\
\text { while the } \\
\text { corresponding } \\
\text { passive delivery } \\
\text { was } 0.26 \\
\text { +/- } 0.16 \text { mg. } \\
\text { The in vitro } \\
\text { experiments } \\
\text { confirmed } \\
\text { iontophoretic } \\
\text { delivery of } \\
\text { dexamethasone } \\
\text { phosphate } \\
\text { across artificial } \\
\text { membranes, } \\
\text { and the in vivo } \\
\text { experiments } \\
\text { suggested that } \\
\text { the drug was } \\
\text { delivered to the } \\
\text { human skin. }\end{array}$ \\
\hline $\begin{array}{c}\text { Brickman } \\
\text { et al. } \\
\text { (2015) }\end{array}$ & $\begin{array}{c}\text { Randomized } \\
\text { control } \\
\text { design }\end{array}$ & 39 patients & $\begin{array}{c}\text { acute soft } \\
\text { tissue injuries }\end{array}$ & once & $\begin{array}{l}\text { Efficacy of iontophoresis } \\
\text { utilizing a transcutaneous } \\
\text { process to transport charged } \\
\text { medication to a localized } \\
\text { area of soft tissue injury via } \\
\text { an electrical current }\end{array}$ & $\begin{array}{l}\text { Comparing } \\
\text { iontophoresis } \\
\text { treatment } \\
\text { with using } \\
\text { lidocaine and } \\
\text { dexamethasone } \\
\text { (n=21) to a } \\
\text { control NSAID } \\
\text { group }(n=18) .\end{array}$ & Level of pain & $\begin{array}{l}\text { At the initiation } \\
\text { of treatment, } \\
\text { average pain } \\
\text { scores for the } \\
\text { treatment } \\
\text { and control } \\
\text { groups were } \\
7.29 \text { and } 6.50 \text {, } \\
\text { respectively. } \\
\text { At } 30 \text { minutes } \\
\text { post-treatment, } \\
\text { a greater } \\
\text { reduction in } \\
\text { pain }(62 \%) \\
\text { was seen in the } \\
\text { iontophoresis } \\
\text { group } \\
\text { compared } \\
\text { reduction in the } \\
\text { control group } \\
\text { (8\%) (p<0.001) }\end{array}$ \\
\hline
\end{tabular}




\begin{tabular}{|c|c|c|c|c|c|c|c|c|}
\hline $\begin{array}{l}\text { Gurney et } \\
\text { al. [5] }\end{array}$ & $\begin{array}{c}\text { Experimental } \\
\text { lab study }\end{array}$ & $\begin{array}{l}16 \text { adults }(10 \\
\text { male, } 6 \text { females; } \\
\text { mean age } 33 \\
\text { years old }\end{array}$ & $\begin{array}{l}\text { Undergoing } \\
\text { anterior } \\
\text { cruciate } \\
\text { ligament } \\
\text { reconstruction }\end{array}$ & $\begin{array}{l}\text { tendon slip was } \\
\text { extracted within } \\
\text { four hours }\end{array}$ & $\begin{array}{l}\text { a } 40 \mathrm{~mA} / \mathrm{min} \text { dose of } \\
\text { iontophoresis with } 0.4 \% \\
\text { DEX-P superficial to a small } \\
\text { piece of the distal semi- } \\
\text { tendinosis tendon before } \\
\text { surgery }\end{array}$ & $\begin{array}{l}\text { transmission of } \\
\text { dexamethasone } \\
\text { sodium } \\
\text { phosphate } \\
\text { (DEX-P) utilizing } \\
\text { iontophoresis } \\
\text { as a task of } \\
\text { skin fold tissue } \\
\text { thickness and } \\
\text { time gone } \\
\text { by between } \\
\text { treatment and } \\
\text { tissue extraction }\end{array}$ & $\begin{array}{l}\text { Absorption/ } \\
\text { concentration } \\
\text { levels }\end{array}$ & $\begin{array}{l}\text { Seven had } \\
\text { measurable } \\
\text { amounts } \\
\text { of DEX-P in } \\
\text { the tendon } \\
\text { slip; average } \\
\text { concentration } \\
\text { of the tendon } \\
\text { tissue in the } \\
16 \text { subjects } \\
\text { was } 2.9 n g / g . \\
\text { No correlation } \\
\text { existed between } \\
\text { DEX-P absorbed } \\
\text { and skinfold } \\
\text { thickness } \\
\text { (r=-0.08, } \mathrm{P} \\
=.79 \text { ) or the } \\
\text { time elapsed } \\
\text { (r =0.25, } \mathrm{P} \\
\text { =.38). Among } \\
\text { the seven } \\
\text { individuals } \\
\text { who showed } \\
\text { measurable } \\
\text { levels of DEX-P } \\
\text { absorbed, } \\
\text { the average } \\
\text { concentration } \\
\text { of DEX-P in the } \\
\text { tendon tissue } \\
\text { was } 6.6 \mathrm{mg} / \mathrm{g} \text {. } \\
\text { There was a } \\
\text { relationship } \\
\text { between DEX-P } \\
\text { concentrations } \\
\text { and time } \\
\text { elapsed, } \\
\text { however not } \\
\text { statistically } \\
\text { significant (r } \\
=0.71, \mathrm{P}=.11) \text {. } \\
\text { Iontophoresis } \\
\text { appeared to } \\
\text { facilitate the } \\
\text { transmission of } \\
\text { dexamethasone } \\
\text { to connective } \\
\text { tissues with } \\
\text { skin fold } \\
\text { thickness up to } \\
\text { at least 30mm } \\
\text { in humans and } \\
\text { the absorption } \\
\text { of the } \\
\text { dexamethasone } \\
\text { appeared } \\
\text { to continue } \\
\text { occurring up to } \\
\text { four hours after } \\
\text { delivery. }\end{array}$ \\
\hline
\end{tabular}




\begin{tabular}{|c|c|c|c|c|c|}
\hline $\begin{array}{l}\text { Gurney et } \\
\text { al. [5] }\end{array}$ & randomized & 29 & $\begin{array}{l}\text { In the true iontophoresis } \\
\text { group (n=16), a } 40 \mathrm{~mA} / \\
\text { min dose of iontophoresis } \\
\text { using a } 0.4 \%(4 \mathrm{mg} / \mathrm{mL}) \\
\text { solution of dexamethasone } \\
\text { was utilized to target the } \\
\text { semitendinosus tendon } \\
\text { just before surgery. The } \\
\text { sham iontophoresis group } \\
\text { (n=13) underwent the same } \\
\text { treatment, but with the } \\
\text { machine off }\end{array}$ & $\begin{array}{l}\text { true } \\
\text { iontophoresis } \\
\text { and sham } \\
\text { iontophoresis; } \\
\text { facilitation of } \\
\text { dexamethasone } \\
\text { absorption } \\
\text { in connective } \\
\text { tissue compared } \\
\text { with diffusion }\end{array}$ & $\begin{array}{l}\text { Statistically } \\
\text { significant } \\
\text { dexamethasone } \\
\text { concentration } \\
\text { difference } \\
\text { between groups } \\
\text { (P=.0216); in } \\
\text { the TI group, } \\
\text { eight had } \\
\text { measurable } \\
\text { amounts of } \\
\text { dexamethasone, } \\
\text { averaging a } \\
\text { concentration } \\
\text { of 2.906mg/g of } \\
\text { tendon tissue. } \\
\text { In the SI group, } \\
\text { one of the } 13 \\
\text { samples had } \\
\text { measurable } \\
\text { amounts of } \\
\text { dexamethasone } \\
\text { averaging a } \\
\text { concentration } \\
\text { of } 0.205 \\
\text { mg/g of } \\
\text { tendon tissue. } \\
\text { Dexamethasone } \\
\text { was not found } \\
\text { in the control } \\
\text { group. Also } \\
\text { show was a } \\
\text { significantly } \\
\text { higher } \\
\text { proportion } \\
\text { of patients } \\
\text { receiving true } \\
\text { iontophoresis } \\
\text { had detectable } \\
\text { levels of } \\
\text { dexamethasone } \\
\text { in their } \\
\text { connective } \\
\text { tissues than } \\
\text { those receiving } \\
\text { a sham } \\
\text { treatment. } \\
\text { Results } \\
\text { suggested that } \\
\text { conditions. } \\
\text { iontophoresis } \\
\text { using } \\
\text { dexamethasone } \\
\text { should be } \\
\text { considered } \\
\text { management of the } \\
\text { of acute } \\
\text { anatory }\end{array}$ \\
\hline
\end{tabular}




\begin{tabular}{|c|c|c|c|c|c|c|c|}
\hline $\begin{array}{l}\text { Rigby et } \\
\text { al. (2015) }\end{array}$ & $\begin{array}{l}\text { Random } \\
\text { assignment }\end{array}$ & 64 & healthy men & $\begin{array}{l}\text { Four groups compared } \\
\text { different mA currents with } \\
\text { different probe depths, } \\
\text { and two others underwent } \\
\text { vivoretrodialysis and skin } \\
\text { perfusion flowmetry }\end{array}$ & $\begin{array}{c}\text { Time course of } \\
\text { dexamethasone } \\
\text { sodium } \\
\text { phosphate to } \\
\text { underlying } \\
\text { tissues using } \\
\text { micro dialysis } \\
\text { during } \\
\text { iontophoresis. }\end{array}$ & $\begin{array}{l}\text { Microdialysis } \\
\text { probes were } \\
\text { used to measure } \\
\text { the combined } \\
\text { recovery (DEX- } \\
\text { total) of DEX-P, } \\
\text { dexamethasone, } \\
\text { and its } \\
\text { metabolite }\end{array}$ & $\begin{array}{l}\text { No difference } \\
\text { in DEX-total } \\
\text { between } \\
\text { current } \\
\text { intensities (P } \\
\text { =.99), but a } \\
\text { larger amount } \\
\text { of DEX-total } \\
\text { was recovered } \\
\text { superficially } \\
\text { at } 1 \text { mm versus } \\
\text { the } 4 \text { mm depth } \\
\text { (P<.0001). } \\
\text { Skin perfusion } \\
\text { returned to } \\
\text { baseline levels } \\
\text { earlier during } \\
\text { 1-mA intensity } \\
\text { at a } 110 \text { mA- } \\
\text { min dose within } \\
\text { the treatment } \\
\text { versus the } 2 \mathrm{~mA} \\
\text { at } 60 \text { minutes } \\
\text { post-treatment. } \\
\text { Based on this } \\
\text { study, DEX-P } \\
\text { iontophoresis } \\
\text { is effective } \\
\text { at clinically } \\
\text { relevant } \\
\text { delivery } \\
\text { concentrations } \\
\text { of DEX-total } \\
\text { to superficial } \\
\text { tendons. DEX- } \\
\text { total recovery } \\
\text { increased } \\
\text { throughout the } \\
\text { iontophoresis } \\
\text { treatment at } \\
\text { similar rates } \\
\text { between } \\
\text { the } 1 \text { and } \\
2 \text { mA current } \\
\text { intensities, } \\
\text { indicating no } \\
\text { difference in } \\
\text { drug delivery } \\
\text { between our } \\
\text { high- and } \\
\text { low-current } \\
\text { intensities up to } \\
\text { a total dose of } \\
\text { 120mA/min. }\end{array}$ \\
\hline
\end{tabular}

Among studies in this systemic review, those of iontophoresis with dexamethasone show plenty of evidence that the combination of treatments may be effective in reducing pain and that there is insufficient evidence supporting the use of corticosteroid iontophoresis. However, the systematic review of Sayegh \& Strauch [11] regarding the effectiveness of physical interventions for lateral epicondylalgia reported contradictions in the results and heterogeneity of the interventions. Additionally, how the drugs intervene with iontophoresis was not considered making it difficult to draw conclusions about the treatment [12-16]. Pooled data from the RCTs point at a lack of intermediate to long-term clinical benefit for the nonsurgical treatment of lateral epicondylitis compared with observation only or placebo.

Of drug treatments, the most frequently used in iontophoresis are dexamethasone and lidocaine. There is evidence supporting the iontophoretic administration of dexamethasone as an alternative to other medication and oral therapy. The current-assisted transdermal delivery of the drug is a non-invasive and safe method, has demonstrated low incidence of side effects, and is a welltolerated therapy. Additionally, studies concerning treatment for epicondylitis using lidocaine reported promising results [16-21]. However, Pedro scores showing lack of quality of these studies as 
well as lack of evidence makes it harder to draw conclusions about the drugs. A few limitations exist in this study. Four studies $([3,5,10]$ Draper et al.) had low Pedro scores (4 or lower) and moderate to low quality of evidence (4). Three studies ([10] Rigby et al.) were of healthy adults with no diagnosis of elbow pain. Lastly, although all but one study was randomized or experimental designs, the number of articles reviewed in this study was limited to 12 that met the inclusion criteria [22-26].

\section{Conclusion}

Evidence was sought related to the clinical effectiveness of iontophoresis in epicondylitis. A sufficient number of studies were considered for this systemic review. All except one study showed good results for the effectiveness of iontophoresis in epicondylitis. However, based on this evidence, it is not conclusive that iontophoresis be recommended as a treatment approach for the management of epicondylitis. Results of this review mostly contradict those of Dimitrios et al. [27] iontophoresis should not be ruled out in treating epicondylitis as it is a dose-response modality, the best treatment dose has not yet been discovered.Therefore more research and review of research is needed on the use of iontophoresis in managing epicondylitis.

\section{References}

1. Bisset L, Paungmali A, Vicenzino B, Beller E (2005) A systematic review and meta-analysis of clinical trials on physical interventions for lateral epicondylalgia. Br J Sports Med 39(7): 411-422.

2. Ciccone C (2007) Pharmacology in rehabilitation ( $4^{\text {th }}$ edn), FA Davis Company, Philadelphia, USA, pp. 416-417.

3. Yarrobino TE, Kalbfleisch JH, Ferslew KE, Panus PC (2006) Lidocaine iontophoresis mediates analgesia in lateral epicondylalgia treatment. Physiother Res Int 11(13): 152-160.

4. www.pedro.org.au/wp-content/uploads/PEDro_scale.pdf

5. Gurney B, Wascher D, Eaton L, Benesh E, Lucak J (2008) The effect of skin Thickness and time in the absorption of dexamethasone in human tendons using iontophoresis. J Orthop Sports Phys Ther 38(5): 238-245.

6. Nirschl RP, Rodin DM, Ochiai DH, Moe MC (2003) Iontophoretic administration of dexamethasone sodium phosphate for acute epicondylitis: A randomized, double-blinded, placebo-controlled study. Am J Sports Med 31(2): 189-195.

7. Runeson, L, Haker E (2002) Iontophoresis with cortisone in the treatment of lateral epicondylalgia (tennis elbow): A double-blind study. Scand J Med Sci Sports 12(3): 136-142.

8. Wen DY, Schultz BJ, Schaal B, Graham ST, Kim BS (2011) Eccentric strengthening for chronic lateral epicondylosis: A prospective randomized study. Sports Health 3(6): 500-503.

9. Stefanou A, Marshall N, Holdan W, Siddiqui A (2012) A randomized study comparing corticosteroid injection to corticosteroid iontophoresis for lateral epicondylitis. J Hand Surg Am 37(1): 104-109.
10. Anderson CR, Morris RL, Boeh SD, Panus PC, Sembrowich WL (2003) Effects of iontophoresis current magnitude and duration on dexamethasone deposition and localized drug retention. Phys Ther 83(2): 161-170

11. Sayegh ET, Strauch RJ (2014) Does nonsurgical treatment improve longitudinal outcomes of lateral epicondylitis over no treatment? A meta-analysis. Clin Orthop Relat Res 473(3): 1093-1107.

12. Baskurt F, Ozcan A, Algun C (2003) Comparison of effects of phonophoresis and iontophoresis of naproxen in the treatment of lateral epicondylitis. Clin Rehabil 17(1): 96-100.

13. Bożena, Latała DM (2009) Physical therapy in treatment of lateral and medial epicondylitis. Physiotheraphy 17(1): 3-10.

14. Neeter C, Thomeé R, Silbernagel KG, Thomeé P, Karlsson J (2003) Iontophoresis with or without dexamethazone in the treatment of acute Achilles. Scand J Med Sci Sports 13(6): 376-382.

15. Demirtas RN, Oner C (1998) The treatment of lateral epicondylitis by iontophoresis of sodium salicylate and sodium diclofenac. Clin Rehabil 12(1): 23-29.

16. Cullinane FL, Boocock MG, Trevelyan FC (2014) Is eccentric exercise an effective treatment for lateral epicondylitis? A systematic Review. Clin Rehabil 28(1): 3-19.

17. Hamann H, Hodges M, Evans B (2006) Effectiveness of iontophoresis of anti-inflammatory medications in the treatment of common musculoskeletal inflammatory conditions: A systematic review. Physical Therapy Reviews 11(3): 190-194

18. Hamilton P (1986) The prevalence of humeral epicondylitis: a survey. J R Coll Gen Pract 36(291): 464-465.

19. Jeske CT (1995) Iontophoresis: Applications in transdermal medication delivery. Phys Ther 75(6): 554-563.

20. Panzade P, Puranik P (2012) Iontophoresis: A functional approach for enhancement of transdermal drug delivery. Asian Journal of Biomedical and Pharmaceutical Sciences 2(11): 1-8.

21. Rawat S, Vengurlekar S, Rakesh B, Jain S, Srikart (2008) Transdermal delivery by iontophoresis. Indian J Pharm Sci 70(1): 5-10.

22. Rothschild B (2013) Mechanical solution for a mechanical problem: Tennis elbow. World J Orthop 4(3):103-106.

23. Schleicher I, Szalay G, Kordelle (2010) Treatment of epicondylitis-A current review. Sportverletz Sportschaden 24(4): 218-224

24. Sims SE, Miller K, Elfar JC, Hammert WC (2014) Non-surgical treatment of lateral epicondylitis: a systematic review of randomized controlled trials. Hand 9(4): 419-446.

25. Singh, Kumar PS, Easwari TS, Shukla VK, Ramkumar C (2011) Iontophoretic delivery of drugs: Maximizing treatment effectiveness. International Journal of Pharmaceutical Sciences Letters 1(2): 28-33.

26. Trudel D, Duley J, Zastrow I, Kerr EW, Davidson R, et al. (2004) Rehabilitation for patients with lateral epicondylitis: A systematic review. J Hand Ther 17(2): 243-266.

27. Apostolos SD, Dimosthenis S, Dimitrios S (2014) The influence of dexamethasone with lidocaine hydrochloride iontophoresis in recreational tennis players suffering from lateral elbow tendinopathy. Journal of Hand Therapy 1(4): 114. 